\title{
A Case of Metastasizing Pleomorphic Adenoma Recurred as Cervical Lymph Node Metastasis after Parotidectomy
}

\author{
Ki Ha Hwang, Hyun Soo Cho, Dong Hoon Kang, and Dongbin Ahn \\ Department of Otolaryngology-Head and Neck Surgery, School of Medicine, Kyungpook National University, Daegu, Korea
}

\author{
이하선 절제술 후 경부 림프절 전이로 재발한 전이성 다형선종 1 예 \\ 황기하· 조현수· 강동훈· 안동빈 \\ 경북대학교 의학전문대학원 이비인후-두경부외과학교실
}

\author{
Received May 15, 2014 \\ Revised July 12, 2014 \\ Accepted July 25, 2014 \\ Address for correspondence \\ Dongbin Ahn, MD \\ Department of Otolaryngology- \\ Head and Neck Surgery, \\ School of Medicine, \\ Kyungpook National University, \\ 130 Dongdeok-ro, Jung-gu, \\ Daegu 700-721, Korea \\ Tel : $+82-53-200-2792$ \\ Fax : +82-53-200-2027 \\ E-mail : godlikeu@naver.com
}

\begin{abstract}
Metastasizing pleomorphic adenoma is a rare condition of metastasis from a histologically benign pleomorphic adenoma of the salivary glands. The bones and lungs are the most common metastatic locations for metastasizing pleomorphic adenoma, suggesting hematogenous spread of the primary tumor. However, we observed a case of metastasizing pleomorphic adenoma presenting with cervical lymph node metastasis, suggesting metastasis through the regional lymphatic system, in a 37-year-old woman who underwent parotidectomy 14 years earlier. Herein, we report this rare case and review the relevant literature.
\end{abstract}

Korean J Otorhinolaryngol-Head Neck Surg 2015;58(2):134-7

Key Words Lymph node · Metastasis · Pleomorphic adenoma - Recurrence.

\section{서 론}

다형선종은 타액선 종양 중 가장 흔하며, 주로 이하선에서 발생하고 전체 타액선 종양의 약 $65 \%$ 를 차지한다. ${ }^{1)}$ 다형선 종은 비록 조직학적으로 양성이지만 불완전한 피막을 뚫고 위족(pseudopod)을 내어 현미경적 침습을 보이기도 하며, 때 로는 위성결절(satellite nodule)을 가지는 경우도 있다. 이러 한 다형선종의 특징 때문에 종양의 수술적 제거에 있어 종양 만을 적출하거나 수술 중 종양의 피막이 찢어지는 경우 불완 전 절제의 원인이 되며, 이러한 경우 수년 후 원발 부위에 재 발할 수 있다. 따라서 다형선종의 수술적 제거 원칙은 일반적 인 양성종양과는 달리 충분한 절제연을 두고 정상 침샘 조직 을 포함하여 절제하는 것이다. ${ }^{2)}$ 다형선종이 재발하는 경우, 장기간의 잠복기간 동안 악성 변환을 거쳐 다형선종 유래암 종(carcinoma ex pleomorphic adenoma)이나 암육종(car- cinosarcoma)의 형태로 재발할 수도 있고, 조직학적으로 여 전히 양성의 형태를 유지한 채로 재발할 수도 있다. ${ }^{1)}$ 이 중 조직학적으로는 양성이면서 원발부위 이외에 추가적인 전이 가 있는 경우를 전이성 다형선종이라고 한다. ${ }^{3}$ 이에 대한 보 고는 극히 드물어서 아직까지 그 임상적 특징에 대해 자세히 연구된 바는 없으며, 국내에서도 현재까지 4예의 증례보고만 이 있다. ${ }^{47}$ 최근 저자들은 14 년 전 이하선 절제술 후 경부 림 프절 전이로 나타난 전이성 재발 다형선종 1 예를 경험하였기 에 이를 문헌고찰과 함께 보고하는 바이다.

\section{증 례}

37세 여자 환자가 좌측 경부의 다발성 종물을 주소로 내 원하였다. 환자는 약 14 년 전 타 병원에서 좌측 이하선 종양 으로 이하선 절제술을 시행 받은 병력이 있었으나 정확한 조 

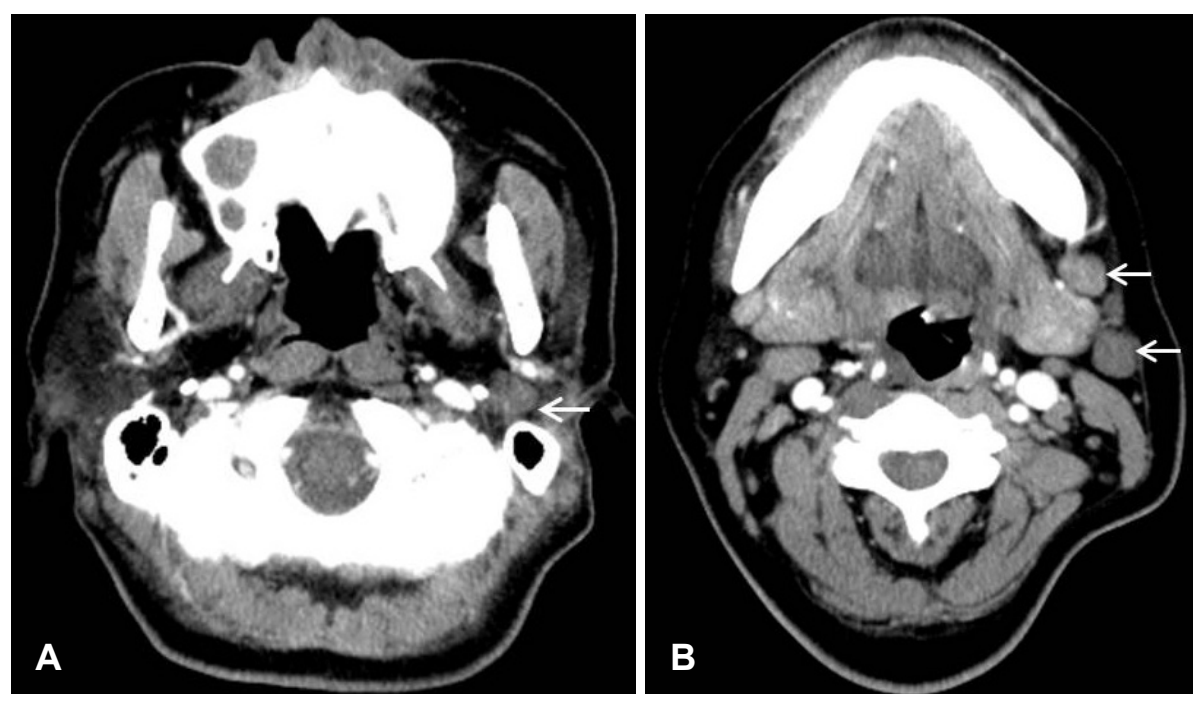

Fig. 1. Preoperative computed tomography scan of the neck shows a $1.5-\mathrm{cm}$ isodense mass (arrow) around the left stylomastoid foramen $(A)$ and metastatic lymph nodes (arrows) in the ipsilateral level I and II regions (B).

직검사 결과에 대해서는 알지 못하였으며, 본원 내원 2 3개 월 전부터 이전 수술 부위 및 하악각 주변, 그리고 경부에 다 발성으로 경부 종물이 촉진되어 타 병원에서 세침흡입검사 후 본원으로 전원되었다. 이전 병원에서 시행한 세침흡입검 사 결과에서는 전이성 암종이 의심된다는 판독 소견을 확인 할 수 있었다. 환자의 개인력 및 가족력에서는 특이 소견 없었 으며, 신체검사에서 좌측 이하선 수술 부위에 약 $2 \times 3 \mathrm{~cm}$, 좌 측 경부 level I III에 약 $1 \sim 2 \mathrm{~cm}$ 가량의 단단한 종물이 다발성 으로 촉지되었다. 검진상 특별히 통증이나 압통을 호소하지 는 않았으며, 종물이 비교적 견고하고 단단하였으나 주변조 직에 고정되어 있지는 않은 양상이었다.

경부 전산화 단층촬영에서 좌측 이하선 절제술 후 상태임 을 확인할 수 있었으며, 좌측 경유돌공(stylomastoid fora$\mathrm{men}$ )과 인접부위에 $1.5 \times 1.5 \mathrm{~cm}$, 좌측 경부 level I III에 걸 쳐 1 2 $\mathrm{cm}$ 전후의 결절들이 여러 개 관찰되었다(Fig. 1). 이 전 병원에서 시행한 세침흡입검사 판독상 명확한 악성의 진 단이 내려지지 않았기 때문에 본과에서 좌측 경부 level III 의 경부 종물에 대해 초음파 유도 세침흡입검사를 추가로 시 행하였으며, 그 결과상 악성 소견은 보이지 않는 일반적인 다 형선종의 소견을 보였다. 이에 전이성 다형선종 및 전이성 암 종의 가능성을 모두 염두에 두고 추가적인 병변의 확인을 위 해 PET/CT를 시행하였으며, 경부 전이 이외의 다른 전이성 병변은 없는 것을 확인할 수 있었다(Fig. 2).

종양의 수술적 제거 및 조직학적 확진을 위해 전신마취하 좌측 이하선 완전 절제술 및 좌측 선택적 경부 림프절 곽청 술을 시행하였다. 이전 수술의 흥터 조직으로 인해 안면신경 탐색에 어려움이 있었으나, 신경 손상 없이 주가지(main trunk)를 찾을 수 있었다. 하지만 안면신경 주가지 및 각 분 지들 주위에 신경과 일부 유착되어 있는 다발성의 종양들을

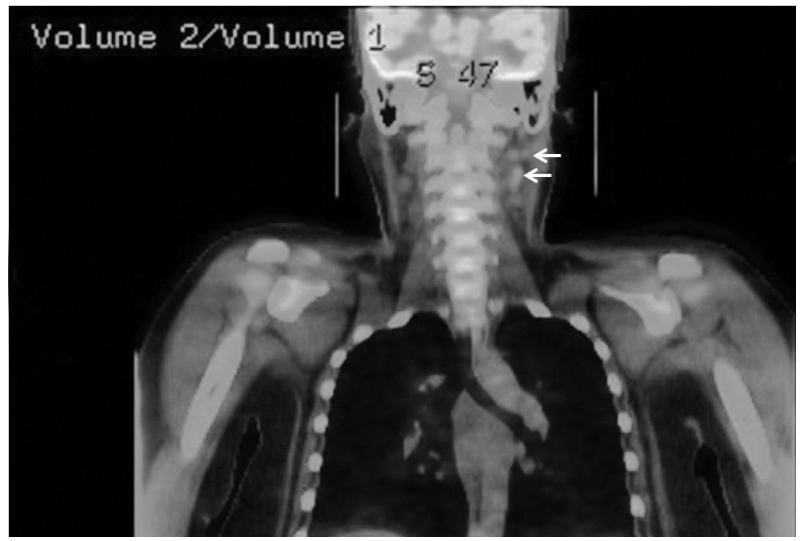

Fig. 2. Preoperative positron emission tomography-computed tomography scan demonstrates several lymph node metastases (arrows) in the left level I-III regions, with no evidence of distant metastasis.

확인할 수 있었으며, 이들 중 안면신경의 협부가지(buccal branch)와 심한 유착을 보인 종양은 신경과 박리가 되지 않 아 해당 신경을 포함하여 일괴로 제거하였다. 그 외 나머지 안면신경의 분지들은 보존할 수 있었으며, 경부 전이성 병변 에 대해 추가적으로 좌측 경부 level I III 림프절 곽청술을 시행한 후 수술을 종료하였다(Fig. 3).

최종 병리조직검사상 잔존 이하선 조직에서 3 개, 그리고 좌측 경부 level I부터 level III에 걸쳐 제거한 45개의 경부 림프절에서 19 개의 종양들이 확인되었는데, 이들 각각의 현 미경 소견은 여러 층의 근상피세포(myoepithelial cell)가 내 층 도관세포를 둘러싸고 있는 관상 구조들이 방추세포가 포 함되어 있는 점액양 기질 내에 혼합되어 있는 형태로, 전형적 인 다형선종의 모습을 보이고 있어 최종적으로 재발성 전이 성 다형선종으로 진단되었다(Fig. 4).

환자는 술 후 House-Brackman grade 3 정도의 안면신경 
Fig. 3. Photographs of the surgical field (A) and specimen (B) after total parotidectomy with selective neck dissection show complete removal of the primary tumor and involved lymph nodes, with preservation of the facial nerve except the buccal branch.
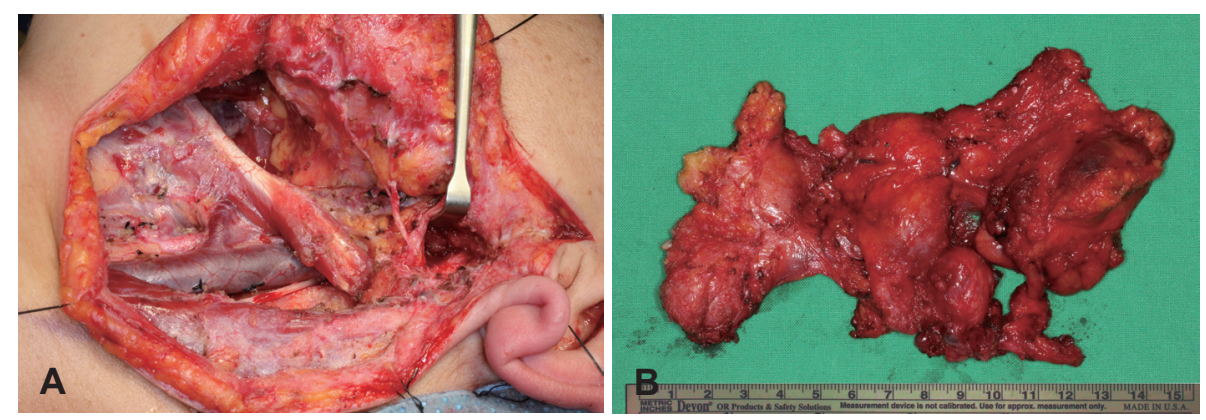

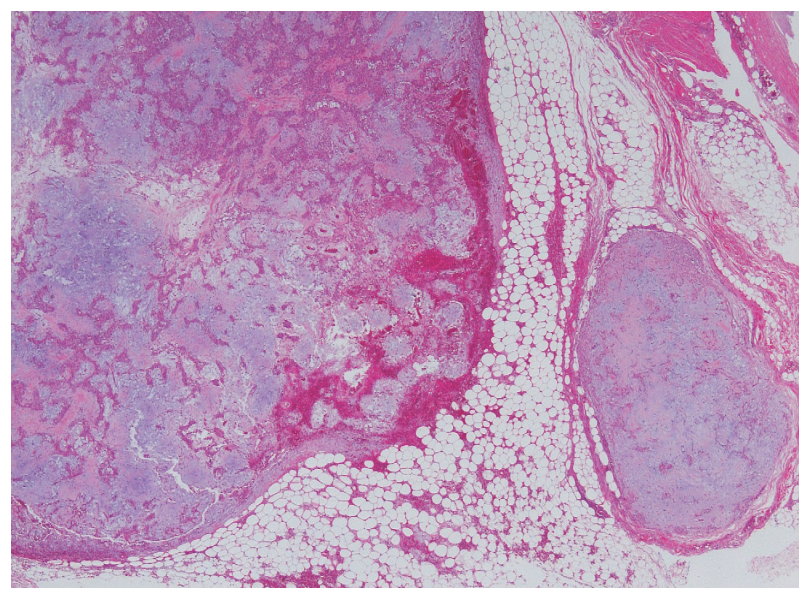

Fig. 4. Low-power view of the neck dissection specimen shows most part of the lymph node has been replaced by the chodromyxoid stroma with benign ductal structure, consistent with a pleomorphic adenoma (hematoxilin and eosin stain, $\times 20$ ).

마비가 발생하였으며, 이에 재활의학과와 협진하여 안면신경 재활치료를 병행하면서 술 후 10 일째 퇴원하였다. 현재는 술 후 5개월째로 안면신경마비는 House-Brackman grade 2 가 량으로 조금 회복되었으며, 재활치료를 지속하며 정기적으로 외래 추적관찰 중이다.

\section{고 찰}

다형선종의 악성 형태인 악성 혼합종에는 다형선종 유래 암종, 암육종, 전이성 다형선종이 있다.,8) 이 중 전이성 다형 선종은 다형선종 유래암종이나 암육종과는 달리 조직학적으 로는 양성의 소견을 가지지만 악성 종양의 특성인 전이를 일 으킨다는 점에서 임상적으로 저등급 악성종양으로 간주되는 매우 특징적인 종양이다." 전이성 다형선종의 대부분은 다형 선종에 대한 초치료 후 재발성으로 나타나게 되는데, 그 시 기는 첫 수술 이후 3 52년 등으로 다양하며 평균 16 17년 후에 발견되는 것으로 보고되고 있다. ${ }^{10,11}$ 또한 전이성 다형 선종의 정의상 전이된 병소의 종양은 원발 부위와 병리조직 학적으로 동일하여야 하기 때문에, ${ }^{12)}$ 대부분의 증례의 경우
전이성 병변에 대한 수술 후에야 비로소 진단이 되는 경우가 많다. 본 증례의 경우는 환자가 타 병원에서 제거한 이전 이하 선 종양의 정확한 병리진단은 알지 못하였으나, 14년 전 수술 후 다시 잔존 이하선 및 경부에 다발성으로 다형선종이 발생한 것으로 보아 처음 원발 부위의 병리진단 역시 다형선종으로 생 각할 수 있었다.

이렇게 환자의 병력상 과거 다형선종 수술 후 종물이 다시 발생한 경우 악성 혼합종의 가장 흔한 형태인 다형선종 유래 암종과의 감별 진단이 중요한데, 다형선종 유래암종의 경우 실제 다형선종의 상피세포가 악성화하여 발생하기 때문에 타액선에서 발생할 수 있는 모든 악성 종양의 형태가 혼재되 어 나타날 수 있으며, 일반적으로 미분화 선암종(poorly differentiated adenocarcinoma)이나 타액관 암종(salivary duct carcinoma)의 형태를 주로 나타내어 병리학적으로 양성 세포로만 구성된 전이성 다형선종과는 분명한 차이를 보인다. ${ }^{8}$

전이성 다형선종의 전이 경로에 대해서는 아직 정확하게 밝혀진 바는 없지만, 대부분의 증례에서 수술 후 발생했다는 점에서 불완전한 절제에 의한 종양세포의 혈행성 전이 가설 이 가장 유력하게 제시되고 있다.,611) 즉, 다형선종이 갖는 불 완전한 피막이나 위족 등의 조직학적 특성 때문에 종양만을 적출하거나 수술 중 종양의 피막이 찢어지는 경우 불완전 제 거의 원인이 되며, 이렇게 남는 종양 세포가 혈관 내로 착상 되어 전이를 일으킬 수 있다는 내용이다. 실제 1998년 Henriksson 등 ${ }^{8}$ 의 보고에 따르면 재발성 다형선종의 경우 9 예 중 5예(55.6\%)에서 위족이 관찰되었고, 원발성 종양에서는 197예 중 16 예(8.1\%)에서 위족이 관찰되었다고 보고하여 재발성 다 형선종의 경우에 위족을 가지는 비율이 높다고 발표하였다.

2012년까지 영문으로 발표된 61개의 전이성 다형선종 증례 를 고찰한 문헌을 살펴보면, 가장 흔한 전이부위는 뼈(28.8\%) 와 폐(26.3\%)였다. ${ }^{10)}$ 본 증례와 같이 경부림프절에 전이를 보 인 경우는 8예에서만 확인되었으며, 기타 구강, 인두, 피부, 간, 후복막, 신장 등에 전이된 경우도 있었다. 이처럼 많은 전 이성 다형선종이 뼈나 폐 등의 원격 장기에 전이를 나타낸다 는 것은 앞서 설명한 혈행성 전이 가설을 뒷받침해주는 근거 
가 되지만, 본 증례와 같이 경부 림프절에 전이를 보이는 전 이성 다형선종의 경우 림프계를 통한 전이 경로 역시 충분히 가능할 것으로 생각된다. ${ }^{13,14)}$ 해부학적으로 이하선 내에는 5 20개의 림프절이 존재하고 이 림프액은 심경부 림프계로 배출되게 되는데, ${ }^{15)}$ 이러한 사실은 본 증례에서 이하선 내의 국소재발이 좌측 경부 level I III 림프절로 전이된 것을 설 명해주는 이론적 배경이 된다고 할 수 있다. 하지만 아직까지 조직학적으로 양성인 전이성 다형선종이 림프절 전이를 일으 키는 보다 세부적인 기전에 대해서는 명확히 알려져 있지 않 다. 다만, 악성종양에서처럼 종양세포가 직접적으로 림프계 를 침범하여 능동적으로 전이를 일으키기보다는, 혈행성 전 이를 설명할 때와 마찬가지로 수술 중 잘못된 조작으로 떨어 져 나온 다형선종 세포가 수술 과정에서 손상된 림프계 내부 로 유입되어 결국 림프절에 생착하게 될 것이라는 가설이 가 장 설득력이 있다. ${ }^{14)}$

처음 발생한 다형선종의 치료와 마찬가지로 전이성 다형선 종의 치료 원칙 역시 완전한 수술적 제거이다. 방사선 치료나 항암치료의 효과는 아직 미미한 것으로 알려져 있으며, 술 후 추가적인 재발을 억제하기 위한 목적의 방사선 치료나 항 암치료 역시 그 효과에 있어서 아직까지 증명된 바가 없다.712) 수술에 있어서는 이하선 절제술 중 피막이 파열되지 않도록 세밀하게 박리하고 충분한 변연을 포함시키는 것이 중요하지 만, 재발한 전이성 다형선종의 경우 이전 수술로 인한 반흔 형성 및 안면신경과의 유착으로 인해 이러한 원칙을 지키는 것은 더욱 어려우므로 실제 전이성 다형선종의 $50 \%$ 에서 술 후 5년 내에 재발하는 것으로 알려져 있다. ${ }^{3)}$ 또한 병리학적 으로 양성임에도 불구하고 최대 $22 \%$ 의 환자에서는 사망에 이른다는 사실을 감안하면, ${ }^{3,7)}$ 무엇보다도 다형선종의 첫 수 술시 항상 재발 및 전이를 염두에 둔 세심하고도 완전한 절 제가 중요하다고 할 수 있겠다. 본 증례와 같이 림프절 전이 가 있는 경우 일반적인 두경부 암의 경부 전이가 있는 것에 준하여 level $\mathrm{I} \mathrm{V}$ 를 포함하는 변형 근치적 경부 림프절 절제 술(modified radical neck dissection)을 할 수도 있겠으나, 저자들의 경우 술 전 경부 초음파 및 경부 전산화단층촬영, 그리고 PET-CT 등의 검사에서 level IV, V에 특별히 의심할 만한 림프절 소견이 없었던 점, 전이성 다형선종이 임상적으 로 저악성도 암종에 속하며 병리학적으로는 양성이라는 점, 그리고 환자가 비교적 젊은 여성이라는 점 등을 고려하여 술 전 환자와 충분히 상의 후 선택적 경부 절제술을 시행하였다.

본 증례는 약 14 년 전 이하선 종양 수술 후 경부 림프절에 전이성 다형선종이 재발한 경우였으며, 혈행성 전이보다는
림프계를 통한 전이가 의심된다는 점에서 특징적이었다. 따 라서 다형선종의 경우 비록 조직학적 양성종양이라 하더라 도 수술 후 재발에 대한 장기적인 추적관찰이 필요할 것으로 생각되며, 추적관찰 중 림프절에 발생한 종물이 확인되는 경 우 전이성 다형선종의 가능성 또한 염두해야 할 것이다. 이에 본 증례를 문헌고찰과 함께 보고하는 바이다.

\section{REFERENCES}

1) Eveson JW, Cawson RA. Salivary gland tumours. A review of 2410 cases with particular reference to histological types, site, age and sex distribution. J Pathol 1985;146(1):51-8.

2) Lee MY, Lee SJ, Kwon MS, Chung PS. Histopathologic analysis of parotid pleomorphic adenoma: resection margin and capsular characterisitcs. Korean J Otorhinolaryngol-Head Neck Surg 2009; 52(2):161-5

3) Nouraei SA, Ferguson MS, Clarke PM, Sandison A, Sandhu GS, Michaels L, et al. Metastasizing pleomorphic salivary adenoma. Arch Otolaryngol Head Neck Surg 2006;132(7):788-93.

4) Cho YM, Lee JY, Koo MB, Yeo CK. Metastasizing pleomorphic adenoma: report of a case. Korean J Otorhinolaryngol-Head Neck Surg 2007;50(8):707-9

5) Chung WS, Kim H, Nam S, Kang JH, Kim YH, Kim ES. Metastasizing pleomorphic adenoma in right lung: a case report. Korean J Thorac Cardiovasc Surg 2007;40(2):143-6.

6) Bae CH, Kim YD, Song SY. Benign pleomorphic adenoma of the soft palate metastasizing to the sphenoid sinus. Clin Exp Otorhinolaryngol 2010;3(3):172-5.

7) Cho YJ, Yang YS, Lee EJ, Hong KH. A case of aggressive local recurrence of metastasizing pleomorphic adenoma with multiple lung metastases. Korean J Otorhinolaryngol-Head Neck Surg 2010; 53(5):320-3.

8) Henriksson G, Westrin KM, Carlsöö B, Silfverswärd C. Recurrent primary pleomorphic adenomas of salivary gland origin: intrasurgical rupture, histopathologic features, and pseudopodia. Cancer 1998;82 (4):617-20.

9) Manucha V, Ioffe OB. Metastasizing pleomorphic adenoma of the salivary gland. Arch Pathol Lab Med 2008;132(9):1445-7.

10) Reiland MD, Koutlas IG, Gopalakrishnan R, Pearson AG, Basi DL. Metastasizing pleomorphic adenoma presents intraorally: a case report and review of the literature. J Oral Maxillofac Surg 2012;70(10): e531-40.

11) Marioni G, Marino F, Stramare R, Marchese-Ragona R, Staffieri A. Benign metastasizing pleomorphic adenoma of the parotid gland: a clinicopathologic puzzle. Head Neck 2003;25(12):1071-6.

12) Steele NP, Wenig BM, Sessions RB. A case of pleomorphic adenoma of the parotid gland metastasizing to a mediastinal lymph node. Am J Otolaryngol 2007;28(2):130-3.

13) Wenig BM, Hitchcock CL, Ellis GL, Gnepp DR. Metastasizing mixed tumor of salivary glands. A clinicopathologic and flow cytometric analysis. Am J Surg Pathol 1992;16(9):845-58.

14) Chen Ih, Tu Hy. Pleomorphic adenoma of the parotid gland metastasizing to the cervical lymph node. Otolaryngol Head Neck Surg 2000;122 (3):455-7.

15) Gavilán J, Herranz J, Desanto LW, Gavilán C. Functional and selective neck dissection. 1st ed. New York: Thieme Medical Publishers; 2002. p.26-33. 